\title{
26 Research Square \\ Potential megathrust earthquakes and tsunamis off the southern coast of West Java, Indonesia
}

Pepen Supendi ( $\square$ pepen_geophysics@yahoo.com )

Institut Teknologi Bandung https://orcid.org/0000-0002-9784-9865

\section{Sri Widiyantoro}

Institut Teknologi Bandung

Abdul Muhari

National Disaster Management Authority

Nicholas Rawlinson

University of Cambridge Central Science Library: University of Cambridge

\section{Supriyanto Rohadi}

Agency for Meteorology Climatology and Geophysics: Badan Meteorologi Klimatologi dan Geofisika

Dwikorita Karnawati

Agency for Meteorology Climatology and Geophysics: Badan Meteorologi Klimatologi dan Geofisika

Nuraini Rahma Hanifa

Institut Teknologi Bandung

Iswandi Imran

Institut Teknologi Bandung

Endra Gunawan

Institut Teknologi Bandung

Lutfi Faizal

Ministry of Public Work and Housing

\section{Research Letter}

Keywords: Earthquake, tsunami, megathrust, West Java

Posted Date: November 13th, 2020

DOl: https://doi.org/10.21203/rs.3.rs-104583/v1

License: (1) This work is licensed under a Creative Commons Attribution 4.0 International License.

Read Full License 


\section{Abstract}

High seismicity rates in and around West Java occur as a result of the Indo-Australian plate converging with and subducting beneath the Sunda plate. Large megathrust events associated with this process likely pose a major earthquake and tsunami hazard to the surrounding community, but further effort is required to help understand both the likelihood and frequency of such events. With this in mind, we exploit catalog and phase data sourced from the Agency for Meteorology, Climatology, and Geophysics (BMKG) of Indonesia and the International Seismological Centre (ISC) for the period of April 2009 through July 2020, in order to conduct earthquake hypocenter relocation using a teleseismic double-difference method. Our results reveal a seismic gap to the south of West Java, which is in agreement with a previous GPS study that finds the same region to be a potential future source of megathrust earthquakes. Tsunami modeling was conducted in the region based on two scenarios using sources from the Indonesian National Center for Earthquake Studies, and show that the maximum tsunami height may be up to $\sim 8 \mathrm{~m}$. This estimate is approximately half the maximum tsunami height predicted by a previous study in which earthquake sources were derived from GPS data inversion.

\section{Introduction}

West Java is located at an active plate boundary between oblique subduction of the Australian plate beneath Sumatra and orthogonal subduction along Java (DeMets et al. 2010). Despite both regions being located along the same active subduction margin, historical data suggest that the portion of western Java in the Sunda arc is relatively aseismic compared to the highly seismically active Sumatra segment. Historical earthquakes in western Java in the early 19 th century have been studied by Newcomb and McCann (1987), who suggested that this particular region experienced two major earthquake events with magnitudes in excess of 7.5, i.e. in 1903 and 1921. Over the last two decades, there were also two major earthquakes that occurred in this area, i.e. the Mw 7.8 thrust fault slow slip event on 17 July 2006, which generated a devastating tsunami in Pangandaran (Fujii and Satake 2006; Mori et al. 2007; Hanifa et al. 2014; Gunawan et al. 2016); and the Mw 6.8 reverse fault earthquake on 2 September 2009, which struck south of western Java (Suardi et al. 2014; Gunawan et al. 2019).

Great earthquakes close to the Java trench are typically interplate faulting events along the slab interface between the Australia and Sunda plates; these earthquakes generally have high tsunamigenic potential due to their shallow depths (Jones et al. 2014). The absence of recent great earthquakes may indicate that even more powerful tsunamigenic events along the south coast of western Java are a potential threat (Widiyantoro et al. 2020). The regions along the southern coast of western Java, e.g., Pelabuhan Ratu, Pangandaran, and south of Banten (Fig. 1) are prone to large earthquakes and their associated tsunamis. However, seismic gaps to the south of western Java are less studied compared to southwest of Sumatra, which is known to generate large megathrust events (Natawidjaja et al. 2004; Chlieh et al. 2008; Konca et al. 2008). 
In this study, we investigate the potential for megathrust earthquakes and consequent tsunamis south of western Java through relocation of earthquake data from April 2009 to July 2020. We also conduct tsunami simulations using megathrust sources provided by the Indonesian National Center for Earthquake Studies (PuSGeN; Irsyam et al. 2020) and compare our results with the interplate coupling sources from GPS data inversions undertaken in previous studies (Hanifa et al. 2014, Widiyantoro et al. 2020). Two different rupture scenarios are tested, with a focus on maximum wave height along the south coast of West Java. Based on tsunamigenic deposit studies by Harris and Major (2017) and Harris et al. (2019), the predicted recurrence interval of large megathrust events is around 500 years.

\section{Data And Method}

\section{a. Seismicity}

We used new data taken from the Indonesian Tsunami Early Warning System (InaTEWS) catalog reported by the Indonesian Agency for Meteorology, Climatology, and Geophysics (BMKG) combined with International Seismological Centre (ISC) catalog data for the period April 2009 through July 2020. Prior to 2009, BMKGs arrival time catalogue is quite limited due to sparse station coverage; this greatly improved with the establishment of InaTEWS. We combined P- and S-waves arrival-time data from 436 seismic stations at local, regional, and teleseismic stations (Fig. S1a). The initial number of earthquakes available in our catalogue is 1,302 . However, prior to relocation, we implement selection criteria to eliminate poorly constrained events. The selection criteria are: (1) each event must produce at least $10 \mathrm{P}$ - and S-phase arrival times, and (2) the azimuthal gaps must be less than $210^{\circ}$ for local/regional stations in the Indonesian network. A total of 1,165 events passed the selection process and were subsequently relocated. The epicentral shifts of relocated events are in general perpendicular (north-south direction) to the Java Trench (Fig. S1b), which may be caused by the stations being mainly distributed to the north on Java.

We used a teleseismic double-difference (DD) relocation algorithm (teletomoDD) that is an extension of the DD tomography method (Zhang and Thurber 2003) to teleseismic distances (Pesicek et al. 2010, 2014). However, in this study we hold the initial seismic velocity model fixed and used the relocation capabilities only, following (Pesicek et al. 2010). Travel times were calculated using a 3D regional seismic velocity model of the Indonesian region with a grid size of $1^{\circ} \times 1^{\circ}$ (Widiyantoro and van der Hilst 1996, 1997; Widiyantoro et al. 2011), and the global 1D model ak135 (Kennett et al. 1995) for regions outside Indonesia, using pseudo-bending ray tracing (Um and Thurber 1987) adapted for use in a spherical coordinate system by Koketsu and Sekine (1998). This ray tracing method allows the use of local, regional, and teleseismic P- and S-wave arrival-time data, thereby helping to mitigate location errors due to insufficient data and large azimuthal gaps in the local seismic network. A total of 20 iterations of the double difference algorithm were applied, which yielded 1,082 well located events (see Fig. 2) and 83 poorly located events that were discarded from the final dataset. The average horizontal change in location from before to after DD relocation is $9.38 \mathrm{~km}$ (Fig. S1b). Comparison of cross sections of hypocenters from the BMKG catalog and the teletomoDD relocation result are show in Fig S2. 


\section{b. Tsunami}

We carried out tsunami modeling with two different megathrust scenarios from PuSGeN (Fig. S3): (1) West-Central Java segments (Mw 8.7), and (2) Combination of Sunda Strait, West-Central Java, and East Java segments (Mw 9.1). The second scenario is based on the fact that the 2004 Sumatra and the 2011 Tōhoku giant earthquake and tsunami events were generated by more than one megathrust segment rupturing simultaneously (Maercklin et al. 2012; Lay 2015; Bilek and Lay 2018).

We modeled the tsunami height using the TUNAMI modelling code of Imamura (1996) and Imamura et al. (1996). To do so, we projected the General Bathymetric Chart of the Oceans (GEBCO) 15 arc-second interval datasets (https://www.gebco.net) onto a rectangular grid of points in latitude ( $5^{\circ}$ to $\left.14^{\circ} \mathrm{S}\right)$ and longitude $\left(103^{\circ}\right.$ to $\left.110^{\circ} \mathrm{E}\right)$. The model domain, which is projected into Cartesian coordinates, has 3120 and 2160 nodes in the $x$ (longitude) and y (latitude) directions, respectively, with a uniform grid spacing of $463 \mathrm{~m}$. The vertical wall boundary condition, which does not allow for the transfer of momentum flux, is used at the coast. This is a common boundary condition for tsunami modelling that prevents on-shore inundation (e.g. Imamura, 1996). We model tsunami propagation using two different source scenarios with various slip distributions by solving the long wave equation of Imamura (1996) with a finite difference method. The first and second scenarios are shown in Fig. S6. Scenario 1 is based on a large event with an estimated magnitude of Mw 8.7, whereas Scenario 2 combines the Sunda Strait, WestCentral Java, and East Java segments to produce an even larger event of Mw 9.1. The various slip distribution sources were modeled using an elastic deformation model (Okada 1985) for each segment. It was assumed that all segments ruptured simultaneously and no account was taken of rupture speed or finite rise time (Fig. 4). The model was run for 5 hours to obtain maximum tsunami height along the south coast of Java.

\section{Results And Discussion}

Our earthquake relocation results for $\mathrm{Mw} \geq 4.0$ illuminate regions located between the coast of West Java and the Java Trench that lack seismicity and hence can be identified as seismic gaps (Fig. 2a). The strongly curved arc of seismicity highlighted in Fig. 2c shows an excellent agreement with the slip deficit map of Hanifa et al. (2014). Since this slip deficit map was derived using GPS data from 2008-2010, our new result indicate that the strain continuously accumulates, at least until June 2020, in this particular region. Further east, the Mw 6.8 earthquake occurred in 2009 (Fig. S4). The seismicity gaps identified in Fig. 2 (a) are still present in a much larger dataset (1963 to 2008) taken from the ISC-EHB catalog (Fig. S5).

Vertical cross-sections A and B in Fig. 3 clearly show that events occur along the megathrust. However, we also detected a near-vertical cluster of events that may be related to a backthrust, as has been found in other locations, e.g. in Sumatra (Pesicek et al. 2010) and in Central Java (Ramdhan et al. 2019). A backthrust occurs as a result of layer-parallel shortening in a late stage of thrust sequences in which it is 
displaced in an opposite direction to that of the main thrust direction (Xu et al. 2015). However, Sirait et al. (2020) has shown that such a feature can also be caused by upward fluid migration.

Ground motion generated by a great earthquake off Java may cause severe damage to megacities such as Jakarta (Nguyen et al. 2015), which is located on a deep basin filled with unconsolidated sediment that amplifies the shaking (Ridwan et al. 2017; Saygin et al. 2017). For instance, the significant earthquakes of magnitude Mw 7.8 (17 July 2006), Mw 6.8 (02 September 2009), Mw 6.5 (15 December 2017), Mw 6.1 (23 January 2018), and Mw 6.9 (02 August 2019) (see the yellow stars in Fig. 2b) shook Jakarta quite severely (MMI up to V; http://shakemap.bmkg.go.id/). Hence, information on seismic gaps that point to the possibility of future megathrust earthquakes along the Java trench is of particular importance for mitigation of seismic and tsunami hazards in the region.

The resulting tsunami heights along the south coast of western Java from Scenario 1 and 2 show that a maximum tsunami height of up to $\sim 8 \mathrm{~m}$ is likely to occur in the region with an average of $1.8 \mathrm{~m}$ for Scenario 1 and $3.3 \mathrm{~m}$ for Scenario 2. In comparison, a tsunami height of up to $\sim 20 \mathrm{~m}$ with an average of $4.5 \mathrm{~m}$ was estimated using slip deficit determined from GPS data (Widiyantoro et al. 2020). Thus, our estimated tsunami height is less than half that of the previous study that assumes the same earthquake magnitude. According to the pioneering work of Aki (1966), the seismic moment is equal to the fault area multiplied by the rigidity and slip of the earthquake source. Assuming the same magnitude and rigidity, the slip of the PuSGeN source is smaller than the source inferred from GPS because the fault area of the PuSGeN source is much larger than that of the GPS source. This explains the difference in maximum estimated wave heights.

\section{Concluding Remarks}

We conducted hypocenter relocation by applying the teletomoDD method to BMKG and ISC catalogs. A total of 1,082 relocated earthquakes $(M w \geq 4.0)$ in West Java for the period April 2009 through July 2020 reveal a seismic gap to the south of the island of Java that is in agreement with results from a previous GPS study. This gap is clearly defined by a strongly curved band of seismicity to the south of Banten. Our relocated events show a near-vertical cluster to the south of West Java, which is likely related to backthrust faulting. The tsunami modeled for two plausible megathrust segments that rupture shows that tsunami heights can reach $\sim 8 \mathrm{~m}$ on the south coast of West Java.

\section{Declarations}

\section{Acknowledgements}

The authors would like to thank BMKG for providing the earthquake data used in this study. This research is partially funded by the Indonesian Ministry of Research and Technology/National Agency for Research and Innovation, and Indonesian Ministry of Education and Culture under World Class University (WCU) Program managed by Institut Teknologi Bandung. 
Availability of data and material

The relocated earthquake catalog data is available in the supplementary material.

\section{Funding}

This research project from Bandung Institute of Technology (ITB) through a research grant 2020 managed by ITB and awarded to S. W.

\section{Authors' contributions}

P. S., S. W. and N. R. wrote the manuscript. All authors reviewed the manuscript. P. S. undertook the relocation of events, and A.M. did the tsunami modelling.

\section{Competing Interests Statement}

We declare that we have no significant competing financial, professional or personal interests that might have influenced the performance or presentation of the work described in this manuscript.

\section{References}

Aki K (1966) Generation and propagation of G waves from the Niigata earthquakeo of June 16, 1964, Estimation of earthquake moment, released energy, and stress-strain drop from G-waves spectrum. Bulletin of the Earthquake Research Institute 44:73-88

Altamimi Z, Métivier L, Rebischung P, et al (2017) ITRF2014 plate motion model. Geophysical Journal International 209:1906-1912. https://doi.org/10.1093/gji/ggx136

Amante C, Eakins (2009) ETOPO1 1 Arc-Minute Global Relief Model: Procedures, Data Sources and Analysis

Bilek SL, Lay T (2018) Subduction zone megathrust earthquakes. Geosphere 14:1468-1500. https://doi.org/10.1130/GES01608.1

Chlieh M, Avouac JP, Sieh K, et al (2008) Heterogeneous coupling of the Sumatran megathrust constrained by geodetic and paleogeodetic measurements. J Geophys Res 113: B05305. https://doi.org/10.1029/2007JB004981

DeMets C, Gordon RG, Argus DF (2010) Geologically current plate motions. Geophysical Journal International 181:1-80. https://doi.org/10.1111/j.1365-246X.2009.04491.x

Fujii Y, Satake K (2006) Source of the July 2006 West Java tsunami estimated from tide gauge records. Geophys Res Lett 33: L24317. https://doi.org/10.1029/2006GL028049 
Gunawan E, Meilano I, Abidin HZ, et al (2016) Investigation of the best coseismic fault model of the 2006 Java tsunami earthquake based on mechanisms of postseismic deformation. Journal of Asian Earth Sciences 117:64-72. https://doi.org/10.1016/j.jseaes.2015.12.003

Gunawan E, Widiyantoro S, Marliyani GI, et al (2019) Fault source of the 2 September 2009 Mw 6.8 Tasikmalaya intraslab earthquake, Indonesia: Analysis from GPS data inversion, tsunami height simulation, and stress transfer. Physics of the Earth and Planetary Interiors 291:54-61. https://doi.org/10.1016/j.pepi.2019.04.004

Hanifa NR, Sagiya T, Kimata F, et al (2014) Interplate coupling model off the southwestern coast of Java, Indonesia, based on continuous GPS data in 2008-2010. Earth and Planetary Science Letters 401:159171. https://doi.org/10.1016/j.epsl.2014.06.010

Harris R, Major J (2017) Waves of destruction in the East Indies: the Wichmann catalogue of earthquakes and tsunami in the Indonesian region from 1538 to 1877. Geological Society, London, Special Publications 441:9-46. https://doi.org/10.1144/SP441.2

Harris R, Meservy W, Stuart K, et al (2019) Seismic and tsunami risk of the Java Trench and implementation of risk reduction strategies. In: SEG Technical Program Expanded Abstracts 2019. Society of Exploration Geophysicists, San Antonio, Texas, pp 4786-4789

Hayes GP, Moore GL, Portner DE, et al (2018) Slab2, a comprehensive subduction zone geometry model. Science 362:58-61. https://doi.org/10.1126/science.aat4723

Imamura F (1996) Review of Tsunami Simulation with a Finite Difference Method. In: Yeh, H., Liu, P. and Synolakis, C., Eds., Long-Wave Run-Up Models. World Scientific, 25-42.

Imamura F, Shuto N, Goto C, Ogawa Y (1996) IUGG/IOC TIME project IOC manual and guides, No. 35.

Irsyam M, Cummins PR, Asrurifak M, et al (2020) Development of the 2017 national seismic hazard maps of Indonesia. Earthquake Spectra 875529302095120. https://doi.org/10.1177/8755293020951206

Jones ES, Hayes GP, Bernardino M, et al (2014) Seismicity of the Earth 1900-2012 Java and vicinity. U.S. Geological Survey

Kennett BLN, Engdahl ER, Buland R (1995) Constraints on seismic velocities in the Earth from traveltimes. Geophysical Journal International 122:108-124. https://doi.org/10.1111/j.1365-246X.1995.tb03540.x

Koketsu K, Sekine S (1998) Pseudo-bending method for three-dimensional seismic ray tracing in a spherical earth with discontinuities. Geophysical Journal International 132:339-346. https://doi.org/10.1046/j.1365-246x.1998.00427.x

Konca AO, Avouac J-P, Sladen A, et al (2008) Partial rupture of a locked patch of the Sumatra megathrust during the 2007 earthquake sequence. Nature 456:631-635. https://doi.org/10.1038/nature07572 
Lay T (2015) The surge of great earthquakes from 2004 to 2014. Earth and Planetary Science Letters 409:133-146. https://doi.org/10.1016/j.epsl.2014.10.047

Maercklin N, Festa G, Colombelli S, Zollo A (2012) Twin ruptures grew to build up the giant 2011 Tohoku, Japan, earthquake. Sci Rep 2:709. https://doi.org/10.1038/srep00709

Mori J, Mooney WD, Afnimar, et al (2007) The 17 July 2006 Tsunami Earthquake in West Java, Indonesia. Seismological Research Letters 78:201-207. https://doi.org/10.1785/gssrl.78.2.201

Natawidjaja DH, Sieh K, Ward SN, et al (2004) Paleogeodetic records of seismic and aseismic subduction from central Sumatran microatolls, Indonesia: PALEOGEODETIC RECORDS OF SUBDUCTION. J Geophys Res 109. https://doi.org/10.1029/2003JB002398

Newcomb KR, McCann WR (1987) Seismic history and seismotectonics of the Sunda Arc. J Geophys Res 92:421. https://doi.org/10.1029/JB092iB01p00421

Nguyen N, Griffin J, Cipta A, Cummins P (2015) Indonesia's Historical Earthquakes Modelled examples for improving the national hazard map

Okada Y (1985) Surface deformation due to shear and tensile faults in a half-space. Bulletin of the Seismological Society of America 75:1135-1154

Pesicek JD, Thurber $\mathrm{CH}$, Zhang H, et al (2010) Teleseismic double-difference relocation of earthquakes along the Sumatra-Andaman subduction zone using a 3-D model. Journal of Geophysical Research 115. https://doi.org/10.1029/2010JB007443

Pesicek JD, Zhang H, Thurber CH (2014) Multiscale Seismic Tomography and Earthquake Relocation Incorporating Differential Time Data: Application to the Maule Subduction Zone, Chile. Bulletin of the Seismological Society of America 104:1037-1044. https://doi.org/10.1785/0120130121

Ramdhan M, Widiyantoro S, Nugraha AD, et al (2019) Detailed seismic imaging of Merapi volcano, Indonesia, from local earthquake travel-time tomography. Journal of Asian Earth Sciences 177:134-145. https://doi.org/10.1016/j.jseaes.2019.03.018

Ridwan M, Widiyantoro S, Irsyam M, et al (2017) Development of an engineering bedrock map beneath Jakarta based on microtremor array measurements. Geological Society, London, Special Publications 441:153-165. https://doi.org/10.1144/SP441.7

Saygin E, Cummins PR, Lumley D (2017) Retrieval of the $P$ wave reflectivity response from autocorrelation of seismic noise: Jakarta Basin, Indonesia. Geophys Res Lett 44:792-799. https://doi.org/10.1002/2016GL071363

Sirait AMM, Meltzer AS, Waldhauser F, et al (2020) Analysis of the 15 December $2017 \mathrm{Mw} 6.5$ and the 23 January 2018 Mw 5.9 Java Earthquakes. Bulletin of the Seismological Society of America. 
Suardi I, Afnimar, Widiyantoro S, Yagi Y (2014) Moment tensor analysis of the september 2, 2009 Tasikmalaya, West Java earthquake using the waveform inversion method of near field data. International Journal of Tomography \& Simulation 25:

Um J, Thurber C (1987) A fast algorithm for two-point seismic ray tracing. Bulletin of the Seismological Society of America 77:972-986

Widiyantoro S, Gunawan E, Muhari A, et al (2020) Implications for megathrust earthquakes and tsunamis from seismic gaps south of Java Indonesia. Sci Rep 10:15274. https://doi.org/10.1038/s41598-02072142-z

Widiyantoro S, Pesicek JD, Thurber CH (2011) Subducting slab structure below the eastern Sunda arc inferred from non-linear seismic tomographic imaging. Geological Society, London, Special Publications 355:139-155. https://doi.org/10.1144/SP355.7

Widiyantoro S, van der Hilst R (1996) Structure and Evolution of Lithospheric Slab Beneath the Sunda Arc, Indonesia. Science 271:1566-1570. https://doi.org/10.1126/science.271.5255.1566

Widiyantoro S, van der Hilst R (1997) Mantle structure beneath Indonesia inferred from high-resolution tomographic imaging. Geophysical Journal International 130:167-182. https://doi.org/10.1111/j.1365246X.1997.tb00996.x

Xu S, Fukuyama E, Ben-Zion Y, Ampuero J-P (2015) Dynamic rupture activation of backthrust fault branching. Tectonophysics 644-645:161-183. https://doi.org/10.1016/j.tecto.2015.01.011

Zhang H, Thurber CH (2003) Double-Difference Tomography: The Method and Its Application to the Hayward Fault, California. Bulletin of the Seismological Society of America 93:1875-1889. https://doi.org/10.1785/0120020190

\section{Figures}




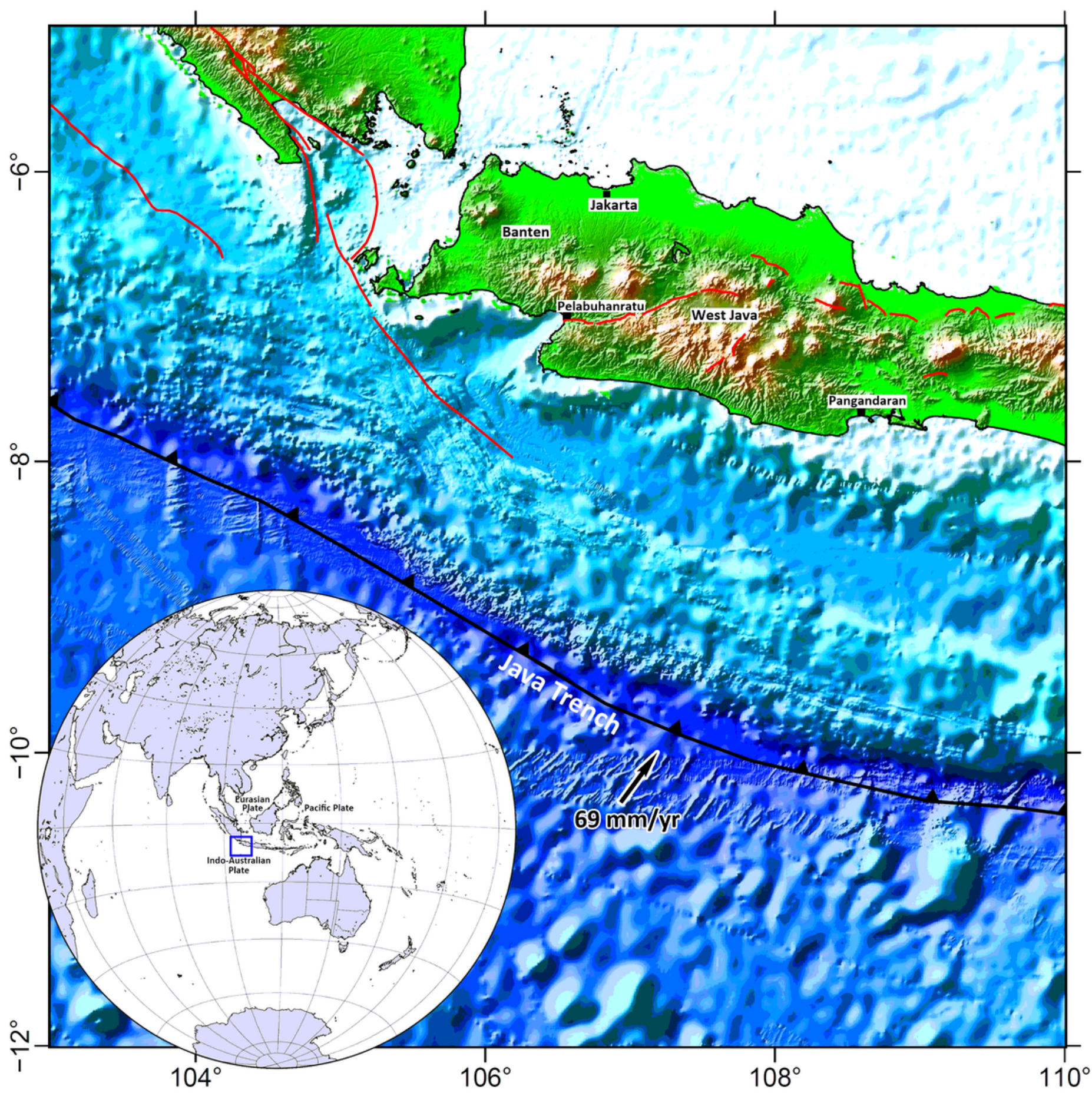

\section{Figure 1}

Map of the study area. Plate motion is from Altamimi et al. (2017). The bathymetry data were taken from ETOPO1 (Amante and Eakins 2009). Inset shows the location of the study area (blue rectangle) with respect to southeast Asia. Red traces correspond to the major crustal faults in the region extracted from Irsyam et al. (2020). 
(a)

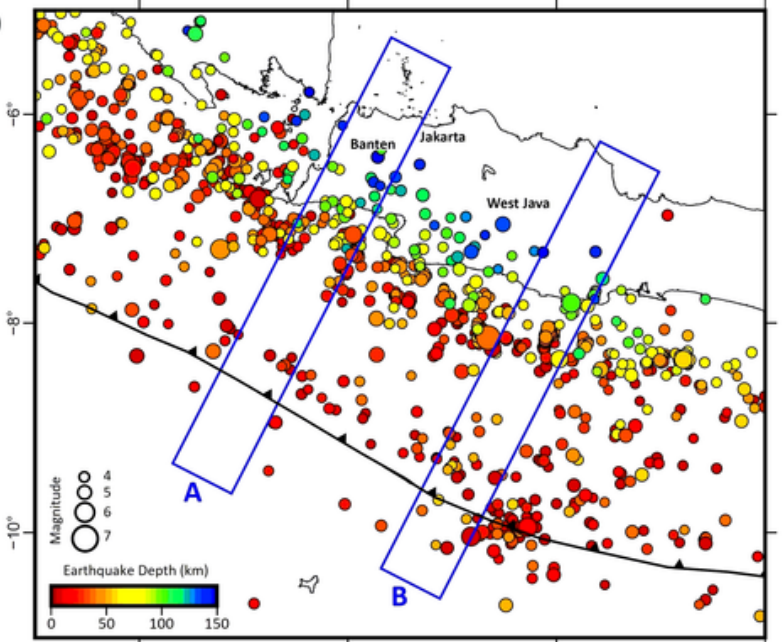

(b)

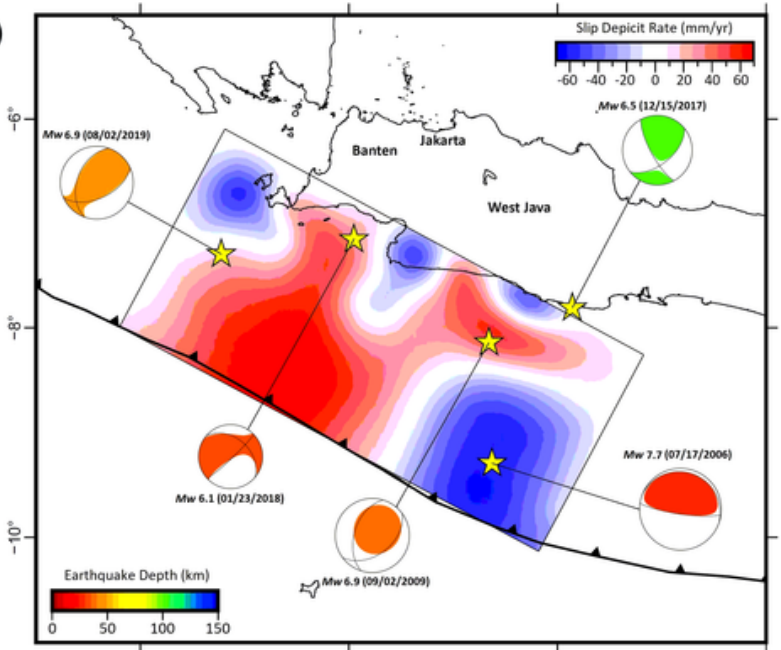

(c)

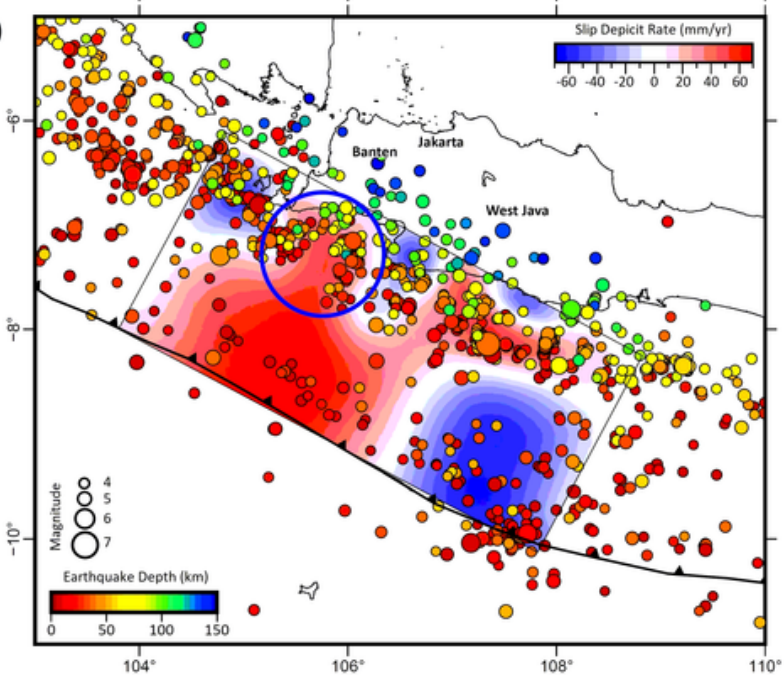

Figure 2

(a) Distribution of the epicenters of relocated earthquakes with magnitude $\geq 4.0$ from April 2009 to July 2020. Blue rectangles ( $A$ and $B$ ) indicate the location of vertical cross sections shown in Fig. 3; (b) Interplate coupling models derived by Hanifa et al. (2014) that reflects the segmentation of the megathrust to the south of Java. Red and blue colors indicate slip deficit and slip excess rates, 
respectively; the yellow stars depict the largest earthquakes for the time period 2006-2019; (c) The epicenter distribution shown in (a) overlaid on the slip deficit model shown in (b).

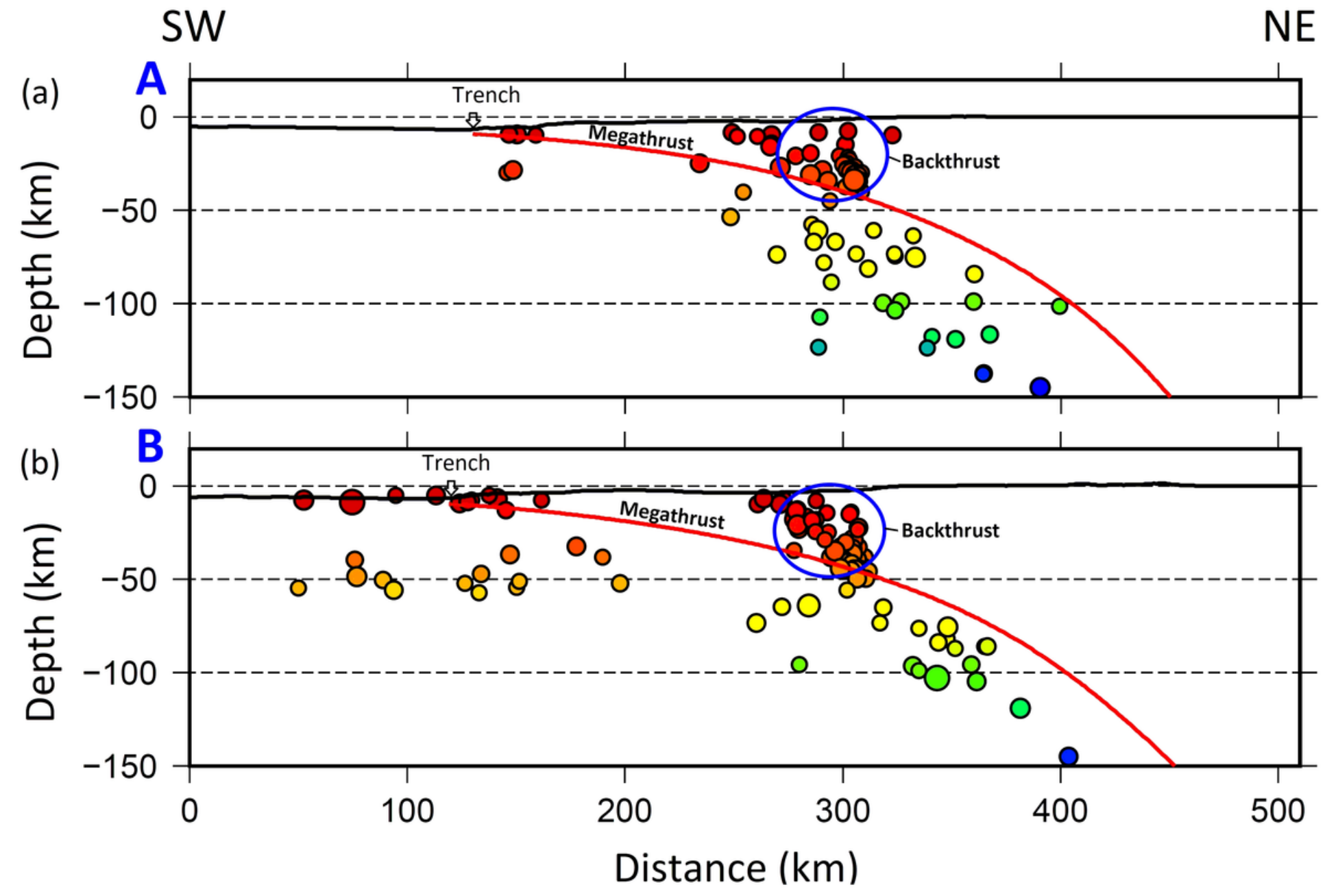

Figure 3

Cross sections of relocated earthquakes with magnitude $\geq 4.0$. The locations of cross sections $A$ and $B$ are shown in Fig. 2a. Red lines depict the upper surface of the subducting Indo-Australian slab according to the Slab 2 model (Hayes et al. 2018). 
(a)

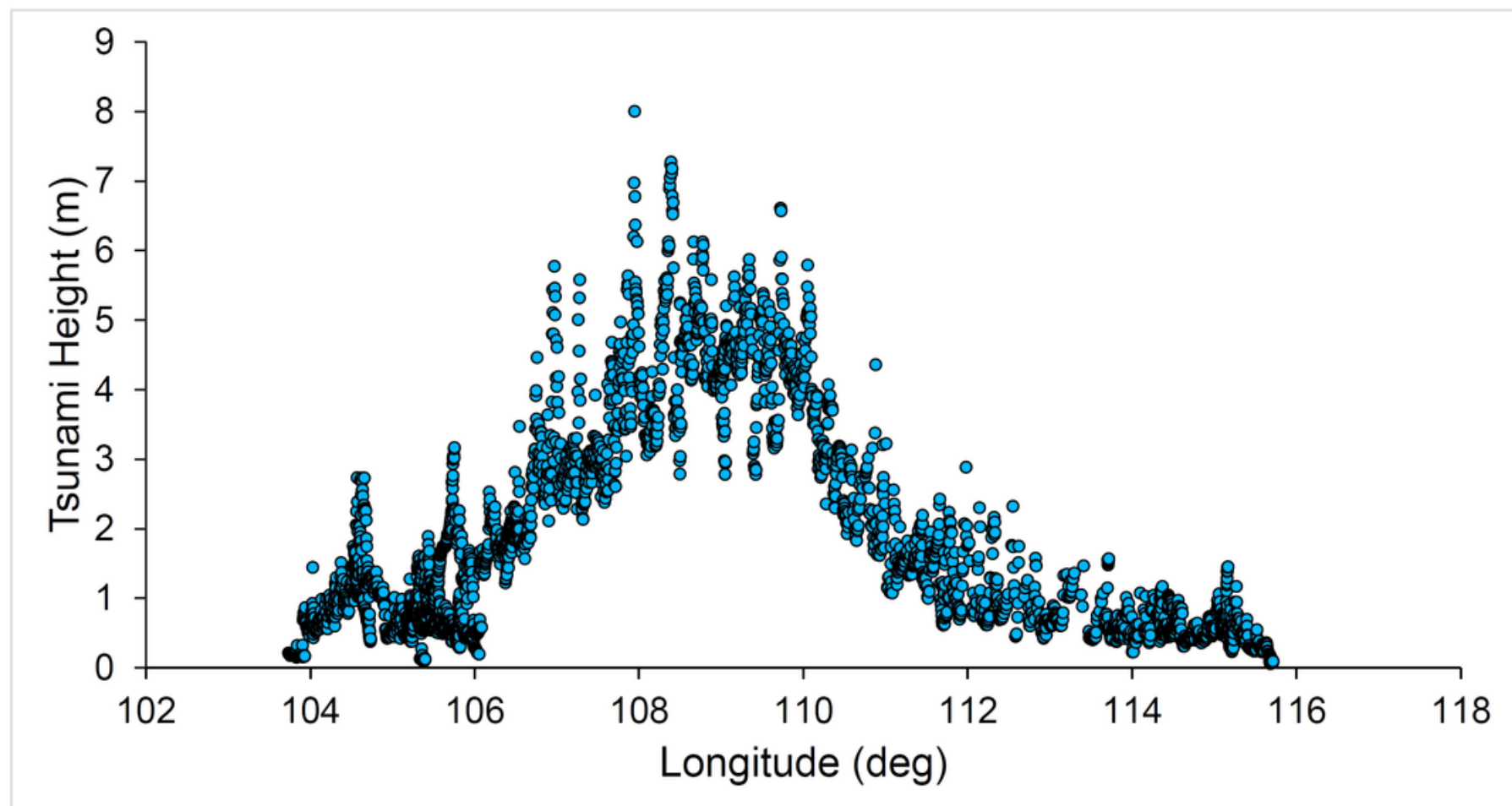

(b)

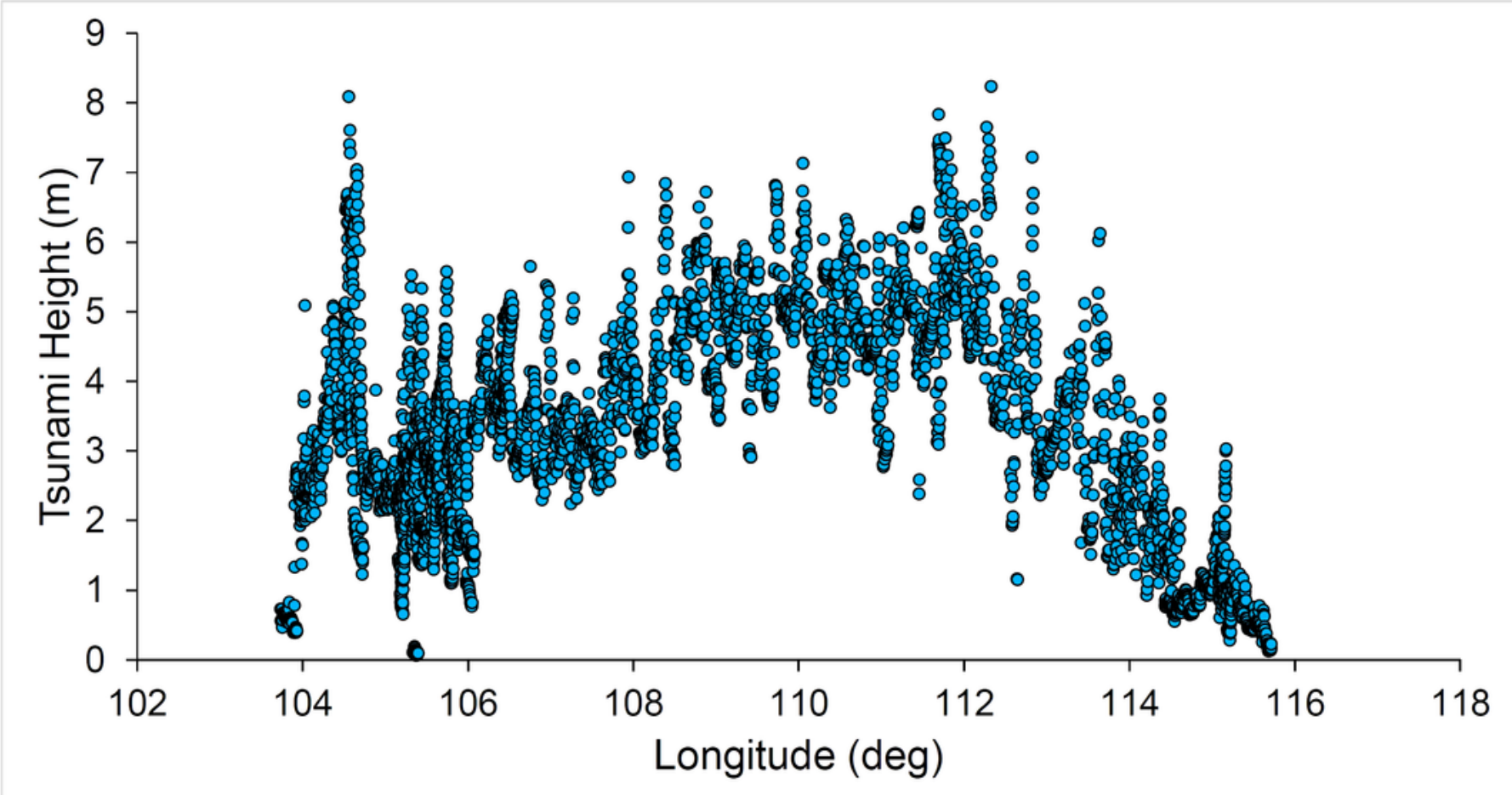

Figure 4

Maximum tsunami height along the south coast of West Java from (a) Scenario 1; (b) Scenario 2.

\section{Supplementary Files}

This is a list of supplementary files associated with this preprint. Click to download. 
- SupplementaryMaterials.docx

Page 14/14 